Citizenship as a Human Right 

Gonçalo Matias

\section{Citizenship as a Human Right}

The Fundamental Right to a Specific Citizenship 
Gonçalo Matias

Catolica Global School of Law

Lisbon, Portugal

ISBN 978-1-137-59383-2

ISBN 978-1-137-59384-9 (eBook)

DOI 10.1057/978-1-137-59384-9

Library of Congress Control Number: 2016942674

(C) The Editor(s) (if applicable) and The Author(s) 2016

The author(s) has/have asserted their right(s) to be identified as the author(s) of this work in accordance with the Copyright, Designs and Patents Act 1988.

This work is subject to copyright. All rights are solely and exclusively licensed by the Publisher, whether the whole or part of the material is concerned, specifically the rights of translation, reprinting, reuse of illustrations, recitation, broadcasting, reproduction on microfilms or in any other physical way, and transmission or information storage and retrieval, electronic adaptation, computer software, or by similar or dissimilar methodology now known or hereafter developed.

The use of general descriptive names, registered names, trademarks, service marks, etc. in this publication does not imply, even in the absence of a specific statement, that such names are exempt from the relevant protective laws and regulations and therefore free for general use. The publisher, the authors and the editors are safe to assume that the advice and information in this book are believed to be true and accurate at the date of publication. Neither the publisher nor the authors or the editors give a warranty, express or implied, with respect to the material contained herein or for any errors or omissions that may have been made.

Cover illustration: (c) ian howard / Alamy Stock Photo

Printed on acid-free paper

This Palgrave Macmillan imprint is published by Springer Nature

The registered company is Macmillan Publishers Ltd. London 


\section{ACKNOWLEDGMENTS}

The research and writing of this book was a long process in the making, starting with the $\mathrm{PhD}$ research, writing, and defense.

I am indebted to many colleagues and friends without whom this book would never be possible.

First and foremost, I am grateful to my supervisors, Rui Medeiros and Stephen H. Legomsky, for their guidance, invaluable support, relentless incentive, and sharp critique. I would have never been able to write this book without their advice and friendship.

An important part of my research was conducted at the Georgetown University Law Centre where I was a Fulbright visiting scholar. I thank T. Alexander Aleinikoff for the opportunity and for the invaluable support.

I would also like to thank my colleagues and staff, both at Universidade Católica Portuguesa in Lisbon and at the Washington University in St. Louis Law School, where I spent time doing research.

A special word is due to Deans Rui Medeiros, Luís Fábrica, Henrique Sousa Antunes, Fernando Ferreira Pinto, Luís Barreto Xavier, and Jorge Pereira da Silva for their continuous support.

I am indebted to Rector Maria da Glória Garcia for the incentive and for the life example that always guided my path.

I thank Professors Jorge Miranda, Mattias Kumm, Miguel Nogueira de Brito, and José Lobo Moutinho for their comments and observations during the thesis defense. 
My dear friends António Araújo, João Taborda da Gama, and Nuno Sampaio were there all the way to help.

This book is dedicated to my parents, Diana, Francisco, and Tomás. They know why.

Lisbon, November 2015

Gonçalo Matias 


\section{Contents}

1 Introduction 1

2 Conceptual Evolution $\quad 7$

3 International Law of Citizenship 41

4 Transnational Citizenship $\quad 79$

5 European Citizenship as a Form of Institutional Transnational Citizenship

6 Migrants' Rights Protection and Migrants as Citizens in Waiting

7 The Right to Citizenship 197

8 Conclusion 239

Bibliography 241

$\begin{array}{ll}\text { Index } & 251\end{array}$ 